\title{
KNOWLEDGE LEVEL OF MEDICAL, PHARMACY AND NURSING STUDENTS ABOUT VACCINATION AND VACCINE SAFETY
}

\author{
Ertuğrul Koçak ${ }^{1}$, Aynur Sanem Yılmaz ${ }^{2}$, Bilge Nur Mutlu², Fatma Kaynak Onurdağ $\breve{g}^{3}$ \\ ${ }^{1}$ Trakya University School of Medicine, Edirne, TURKEY \\ ${ }^{2}$ Trakya University School of Pharmacy, Edirne, TURKEY \\ ${ }^{3}$ Department of Pharmaceutical Microbiology, Trakya University School of Pharmacy, Edirne, TURKEY
}

\begin{abstract}
Aims: This study aims to determine the knowledge level of medical, pharmacy, and nursing students at Trakya University regarding vaccination and vaccine safety. Methods: A questionnaire comprised of 8 questions was completed by 383 students in February 2020. Out of 383 participants, there were 143 medical, 95 pharmacy, and 145 nursing students. The relation of knowledge level with gender, faculty, and the grade were evaluated using the Chi-Square test. Results: Out of 383 students 19.9\% stated that they had no knowledge about national childhood vaccination schedule of Turkey, 14.6\% thought vaccines cause autism, 83.7\% stated that they do not regularly get vaccines recommended for adults, and 68.6\% did not have the proper answer to the question of where vaccination can be applied. Conclusion: Vaccines and vaccine safety concerns health care students closely, yet these students have insufficient knowledge about vaccines. As a solution to this problem, more time can be spared for vaccination and vaccine safety subjects in the curriculum of these faculties. Keywords: Vaccines, vaccination, autism spectrum disorder, students, questionnaire
\end{abstract}

\section{INTRODUCTION}

There have been numerous claims about vaccines in recent years, putting forth a relation with vaccination and different disorders such as immune system dysfunction, Attention-Deficit/Hyperactivity Disorder (ADHD), and autism. Misleading articles and news published in mainstream media, also support these concerns (1). However, studies are showing that there is no association between autism or ADHD and vaccination (2-5).

Some vaccines contain the microorganism that also causes the disease, but these are attenuated microorganisms and are not harmful to the individual. Other vaccines contain only some parts of the microorganism. Vaccines stimulate the immune system to produce the same antibodies as if the individual faced the disease itself, thus vaccinated individual already has the antibodies, without having the disease (6).

The aim of this study is to determine the knowledge level of medical, pharmacy, and nursing students, who are the future health workers, about vaccination, vaccine safety, and concerns about vaccines.

\section{MATERIAL AND METHODS}

This study was approved by the Scientific Research Ethics Committee of Trakya University Medical Faculty (Protocol Code: TÜTF-BAEK 2019-475). The study was performed on 383 voluntary students in February 2020. Participant group size was specified by taking into consideration the attainability. It is a descriptive, cross-sectional study using a questionnaire consisted of 8 questions. The participants were selected on a voluntary basis and the questionnaires were given to participants by hand. The content of the questionnaire and how the data were going to be used were inscribed at the beginning of the questionnaire. 1 st-3rd year medical, 1st-4th year pharmacy, and 1st4th year nursing students from Trakya University participated in the study. The demographic information consisted of the grade and faculty of the participants were questioned to evaluate the association between demographic data and the knowledge level of participants. The relationship between vaccination preferences, knowledge level, and gender were evaluated accor-

Address for Correspondence: Ertuğrul Koçak, Trakya University School of Medicine, Edirne, TURKEY

e-mail: ertugrul.kocak17@gmail.com ORCID: orcid.org/0000-0003-2663-5146

Received: 09.03.2020 Accepted: 11.04.2020 • DOI:10.4274/tmsj.galenos.2020.07.02.05 Available at: tmsj.trakya.edu.tr 
ding to participants' answers to associated questions. The entire questionnaire is presented in Table 1. In the $1 \mathrm{st}, 3 \mathrm{rd}$, 5th, and 6th questions it was aimed to evaluate the knowledge level of the participants on vaccination, and in the $2 \mathrm{nd}, 4 \mathrm{th}, 7 \mathrm{th}$, and 8 th questions it was aimed to question participants' general attitude on vaccine and vaccination. The data was analyzed using IBM SPSS version 20.0. Chi-square test was used on categorical variables. In all statistical analyses, a p-value of $<0.05$ was set for the statistical significance.

Table 1: The questionnaire used in the study.

1- Which one of the below is more descriptive about your knowledge level on national childhood vaccination schedule of Turkey?

I am knowledgeable and I know each vaccine.

I am knowledgeable but I do not know each vaccine.

I am uninformed.

2- Would you consider getting your children vaccinated in the future according to the schedule?

I consider getting my children vaccinated.

I do not consider getting my children vaccinated.

3- What is your opinion about the idea of vaccination causing autism in children?

I think vaccination causes autism in children.

I think some vaccines cause autism in children.

I do not think vaccination causes autism in children.

\section{4- Do you regularly get vaccinated?}

Yes

No

5- Where do you think vaccination is done?

Family Medicine Offices

Community Health Centre

Hospitals

Pharmacies

6- Have you ever heard of the active/inactive vaccine term? Do you have any information?

Yes, I have heard and I am knowledgeable.

Yes, I have heard but I am uninformed.

No, I have not heard of it.

\section{7- Do you find vaccination services in Turkey sufficient?}

Yes, it is sufficient.

No, it is insufficient.

\section{8- Should government follow an obligatory vaccination policy?}

Yes, government should follow an obligatory vaccination policy.

No, government should not follow an obligatory vaccination policy. 


\section{RESULTS}

Out of 383 participants, 127 (33.2\%) were male and $252(65.8 \%)$ were female, $4(1 \%)$ did not specify their genders. Participants who did not specify their genders were included in the study yet excluded from gender-related questions. The demographic distribution of the participants is shown in Table 2 .

The first question aims to evaluate the knowledge level of participants about the national childhood vaccination schedule of Turkey. All the faculties were grouped by the grades and compared separately for this question .

Out of 142 medical students; 14 (9.9\%) 1st year, 11 (7.7\%) 2nd year, and 2 (1.4\%) 3rd year students stated that they did not have enough knowledge about the vaccination schedule. 1 participant did not answer the question (Figure 1). Statistically significant association was found between the grade and knowledge level about vaccination schedule among medical students $(\mathrm{p}=0.049)$.

Out of 95 pharmacy students; 9 (9.5\%) 1st year, $7(7.4 \%)$ 2nd year, 1 (1\%) 3rd year, and $3(3.2 \%) 4$ th year students stated that they did not have enough knowledge about the vaccination schedule and statistically significant association was found between grade and knowledge level about vaccination schedule among pharmacy students $(\mathrm{p}=0.003)$.

Out of 144 nursing students, 15 (10.4\%) 1st year, $10(6.9 \%)$ 2nd year, 3 (2\%) 3rd year, and $1(0.7 \%) 4$ th year students stated that they did not have enough knowledge about the vaccination schedule (Figure 2). Statistically significant association was found between the grade and knowledge level about the vaccination schedule among nursing students $(\mathrm{p}<0.001)$.

Among participants who stated that they did not have enough knowledge about the national childhood vaccination schedule of Turkey, there were $27(35.5 \%)$ medical, 20 (26.3\%) pharmacy, and $29(38.2 \%)$ nursing students. There was no significant difference between the knowledge level of students from different faculties ( $p>0.05)$.

The answers to the second question, asking the students if they would vaccinate their child following the national childhood vaccination schedule of Turkey in the future, are grouped by gender. $6(1.6 \%)$ participants stated they would prefer not to; $1(0.3 \%)$ male and $5(1.3 \%)$ female. There was no significant difference between male and female participants for being anti-vaxxer ( $p>0.05)$.

In the third question, participants were asked if they think vaccines cause autism and the answers were grouped by the faculty and the grade.
One hundred twenty-five (39\%) medical students, 78 (24.4\%) pharmacy students, and 117 (36.6\%) nursing students had the knowledge that no vaccine had the effect of causing autism in children. There was no significant difference between faculty and knowledge level about vaccines $(p>0.05)$. The distribution of answers to question 3 by participants' grade for each faculty is shown in Table 3 . The grade was not found statistically significant for medical students' answers to the third question ( $p>0.05$ ), yet it was found to be significant for pharmacy $(\mathrm{p}=0.023)$ and nursing students $(\mathrm{p}=0.003)$.

Out of 383 students, $62(16.3 \%)$ stated that they get their adulthood vaccines regularly while $318(83.7 \%)$ students stated they do not. 3 participants did not answer the question (Figure 3).

Answers of the fifth question, which was asked to determine if students know where vaccination procedures are done, are grouped by the faculties. 87 (33.2\%) medical, 73 (27.9\%) pharmacy, and 102 (38.9\%) nursing students did not have enough knowledge. Statistically significant association was found between knowing where vaccination procedures are done and faculty $(\mathrm{p}=0.034)$ (Figure 4).

Knowledge level of participants about active/inactive vaccine was asked in the 6th question and answers were grouped by the grade. The distribution by the grade is shown in Table 4. Statistically significant association between being knowledgeable about active/inactive vaccine and the grade was found for all faculties $(\mathrm{p}<0.001)$.

Questions "Do you find vaccination service in Turkey sufficient?" and "Should government follow an obligatory vaccination policy?" were asked to evaluate participants' thoughts and preferences. 186 (49.1\%) participants said they find the vaccination service in Turkey sufficient (Figure 5) and $310(81.2 \%)$ think that government should follow an obligatory vaccination policy (Figure 6). 
Table 2: The demographic distribution of the participants.

\begin{tabular}{lllllll} 
& & $\mathbf{1}^{\text {st }}$ year & $2^{\text {nd }}$ year & $\mathbf{3}^{\text {rd }}$ year & $4^{\text {th }}$ year & Total \\
\hline \multirow{5}{*}{ Faculty } & Medicine & 46 & 59 & 38 & - & $143(37.3 \%)$ \\
& Pharmacy & 23 & 33 & 27 & 12 & $95(24.8 \%)$ \\
& Nursing & 38 & 33 & 42 & 31 & $144^{*}(37.9 \%)$ \\
& Female & 62 & 85 & 70 & 35 & $252(65.8 \%)$ \\
\multirow{2}{*}{ Gender } & Male & 42 & 40 & 37 & 8 & $127(33.2 \%)$ \\
& Unspecified & & & & & $4(1 \%)$ \\
\hline
\end{tabular}

( ${ }^{\star} 1$ student from nursing did not specify his class).

Table 3: The distribution of answers by class and faculty on 3rd question.

\begin{tabular}{|c|c|c|c|c|}
\hline & Class & $\begin{array}{l}\text { Vaccination Causes } \\
\text { Autism in Children }\end{array}$ & $\begin{array}{c}\text { Some Vaccines } \\
\text { Cause Autism in } \\
\text { Children }\end{array}$ & $\begin{array}{c}\text { Vaccination Does } \\
\text { not Cause Autism in } \\
\text { Children }\end{array}$ \\
\hline \multirow{3}{*}{$\begin{array}{l}\text { Medicine } \\
(p=0.664)\end{array}$} & $1^{s t}$ & $1(2.3 \%)$ & $6(14 \%)$ & $36(83.7 \%)$ \\
\hline & $2^{\text {nd }}$ & $1(1.7 \%)$ & $4(6.8 \%)$ & $54(91.5 \%)$ \\
\hline & $3^{\text {rd }}$ & $1(2.6 \%)$ & $2(5.3 \%)$ & $35(92.1 \%)$ \\
\hline \multirow{4}{*}{$\begin{array}{l}\text { Pharmacy } \\
(p=0.023)\end{array}$} & $1^{s t}$ & $1(4.5 \%)$ & $7(31.8 \%)$ & $14(63.6 \%)$ \\
\hline & $2^{\text {nd }}$ & $1(3 \%)$ & $1(3 \%)$ & $31(93.9 \%)$ \\
\hline & $3^{r d}$ & $1(3.8 \%)$ & $4(15.4 \%)$ & $21(80.8 \%)$ \\
\hline & $4^{\text {th }}$ & - & - & $12(100 \%)$ \\
\hline \multirow{4}{*}{$\begin{array}{l}\text { Nursing } \\
(p=0.003)\end{array}$} & $1^{s t}$ & - & $12(31.6 \%)$ & $26(68.4 \%)$ \\
\hline & $2^{\text {nd }}$ & $1(3.2 \%)$ & $3(9.7 \%)$ & $27(87.1 \%)$ \\
\hline & $3^{r d}$ & $1(2.4 \%)$ & $7(16.7 \%)$ & $34(81 \%)$ \\
\hline & $4^{\text {th }}$ & $1(3.2 \%)$ & - & $30(96.8 \%)$ \\
\hline
\end{tabular}

Table 4: The distribution of knowledge level about active/inactive vaccine by class.

\begin{tabular}{|c|c|c|c|c|}
\hline & Class & $\begin{array}{l}\text { Knowledgeable about } \\
\text { active/inactive vaccine }\end{array}$ & $\begin{array}{c}\text { Heard of } \\
\text { active/inactive vaccine } \\
\text { but is uninformed }\end{array}$ & $\begin{array}{c}\text { Uninformed of } \\
\text { active/inactive vaccine }\end{array}$ \\
\hline \multirow{3}{*}{$\begin{array}{l}\text { Medicine } \\
(p<0.001)\end{array}$} & $1^{s t}$ & $21(47.7 \%)$ & $6(13.6 \%)$ & $17(38.6 \%)$ \\
\hline & $2^{\text {nd }}$ & $29(49.2 \%)$ & $20(33.9 \%)$ & $10(16.9 \%)$ \\
\hline & $3^{r d}$ & $33(86.8 \%)$ & $5(13.2 \%)$ & - \\
\hline \multirow{4}{*}{$\begin{array}{l}\text { Pharmacy } \\
(p<0.001)\end{array}$} & $1^{s t}$ & $7(30.4 \%)$ & $6(26.1 \%)$ & $10(43.5 \%)$ \\
\hline & $2^{\text {nd }}$ & $9(27.3 \%)$ & $18(54.5 \%)$ & $6(18.2 \%)$ \\
\hline & $3^{r d}$ & $24(88.9 \%)$ & $3(11.1 \%)$ & - \\
\hline & $4^{\text {th }}$ & $11(100 \%)$ & - & - \\
\hline \multirow{4}{*}{$\begin{array}{l}\text { Nursing } \\
(p<0.001)\end{array}$} & $1^{s t}$ & $10(27 \%)$ & $13(35.1 \%)$ & $14(37.8 \%)$ \\
\hline & $2^{\text {nd }}$ & $18(54.5 \%)$ & $9(27.3 \%)$ & $6(18.2 \%)$ \\
\hline & $3^{r d}$ & $28(66.7 \%)$ & $10(23.8 \%)$ & $4(9.5 \%)$ \\
\hline & $4^{\text {th }}$ & $30(96.8 \%)$ & $1(3.2 \%)$ & - \\
\hline
\end{tabular}




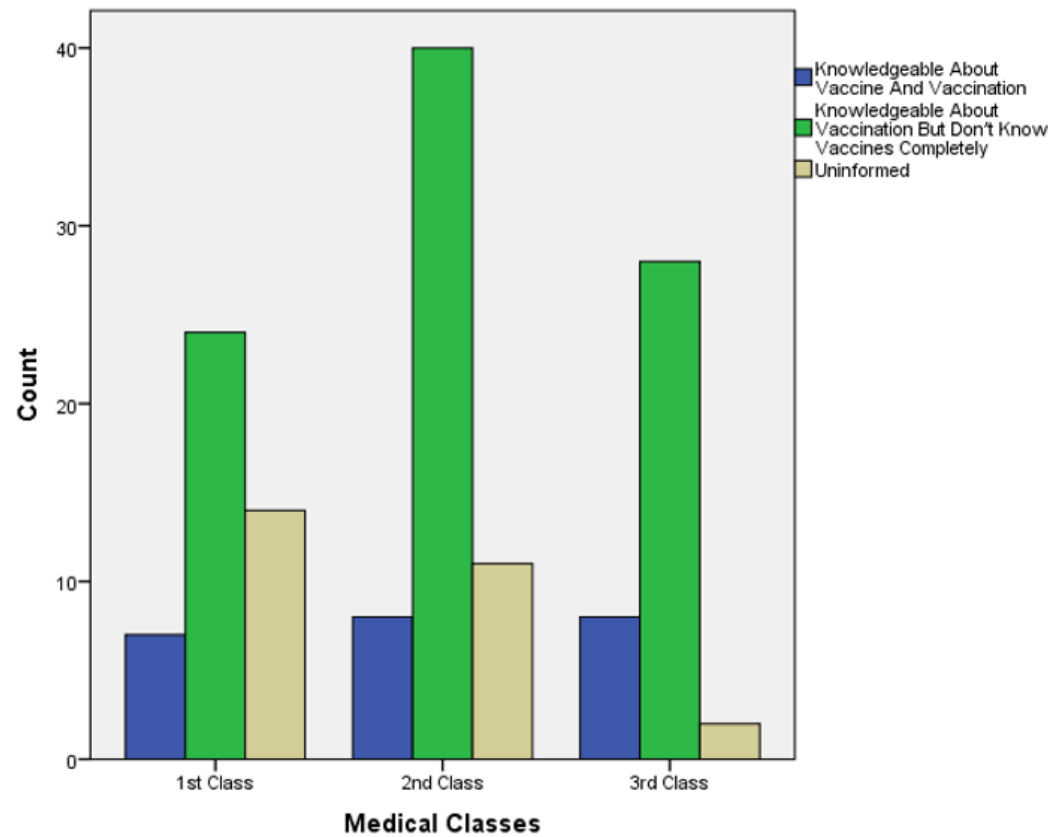

Figure 1: The distribution of medical students' answers by class for the first question.

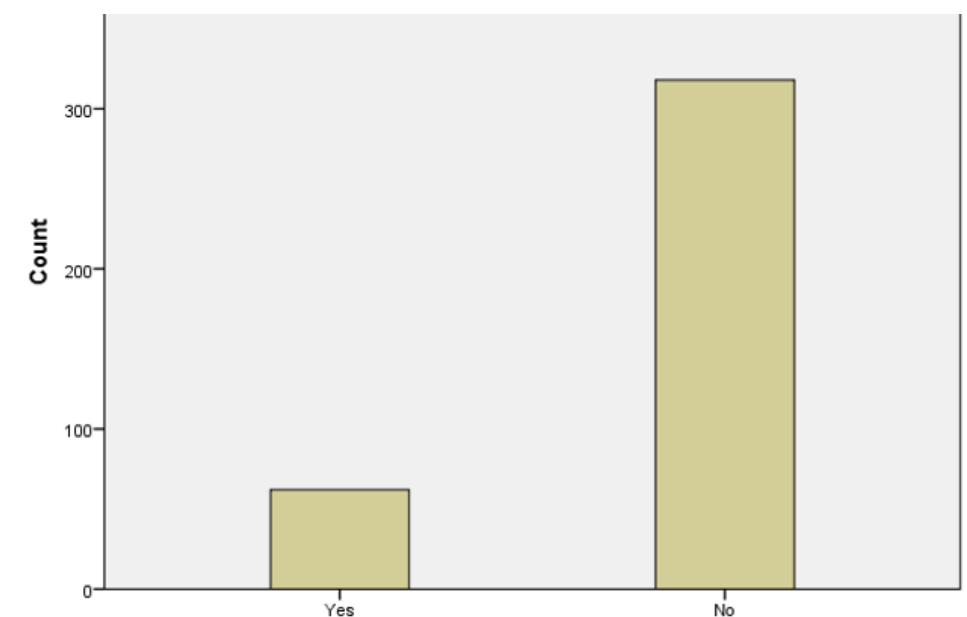

Is There Any Vaccine You Get Regularly?

Figure 3: Regularly done adulthood vaccination among participants.

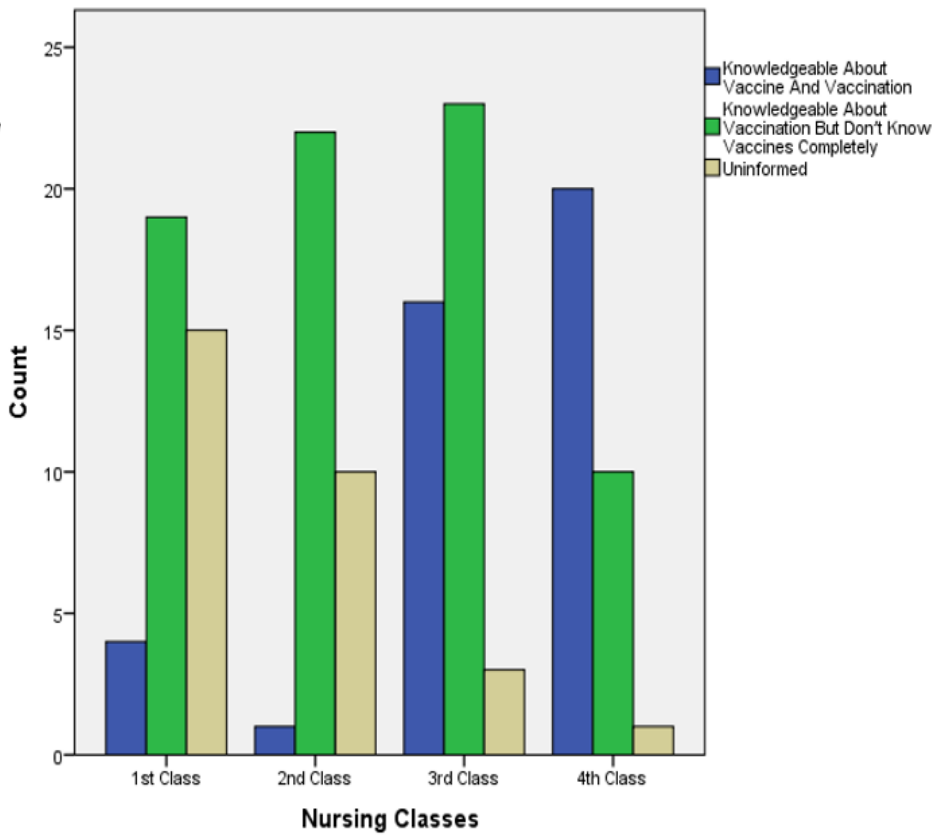

Figure 2: The distribution of nursing students' answers by class for the first question.

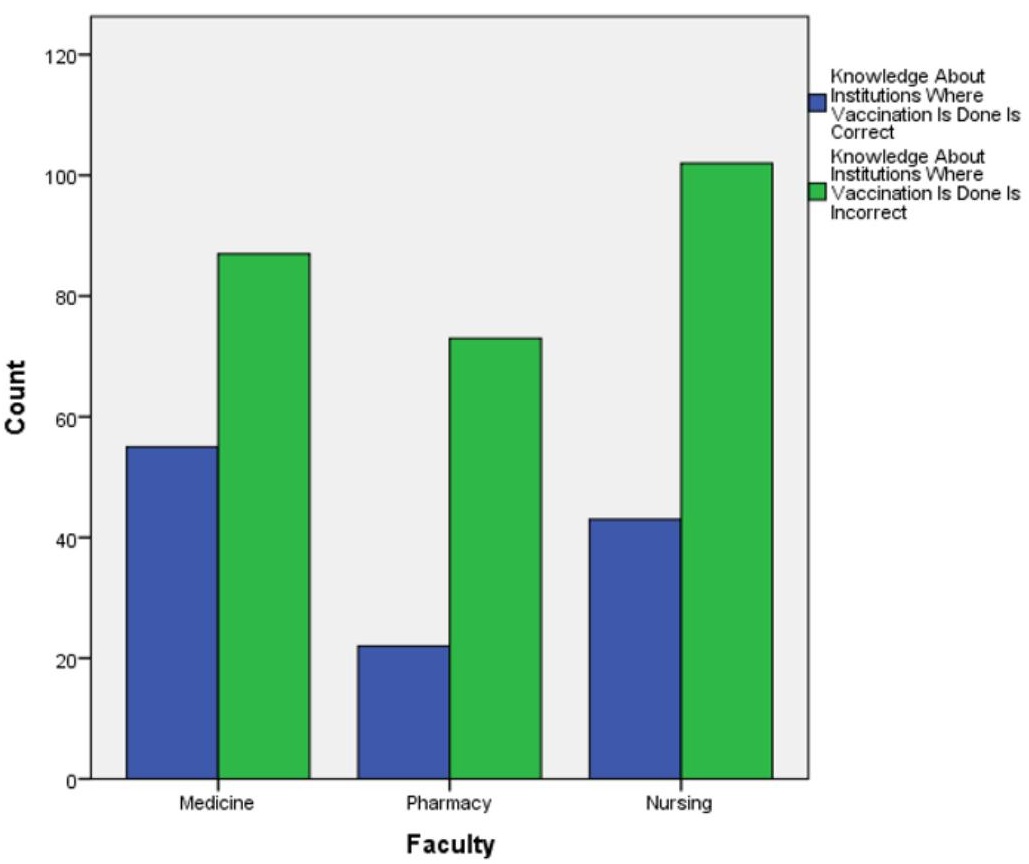

Figure 4: Accuracy of participants knowledge on the question of "Where do you think vaccination is done?". 


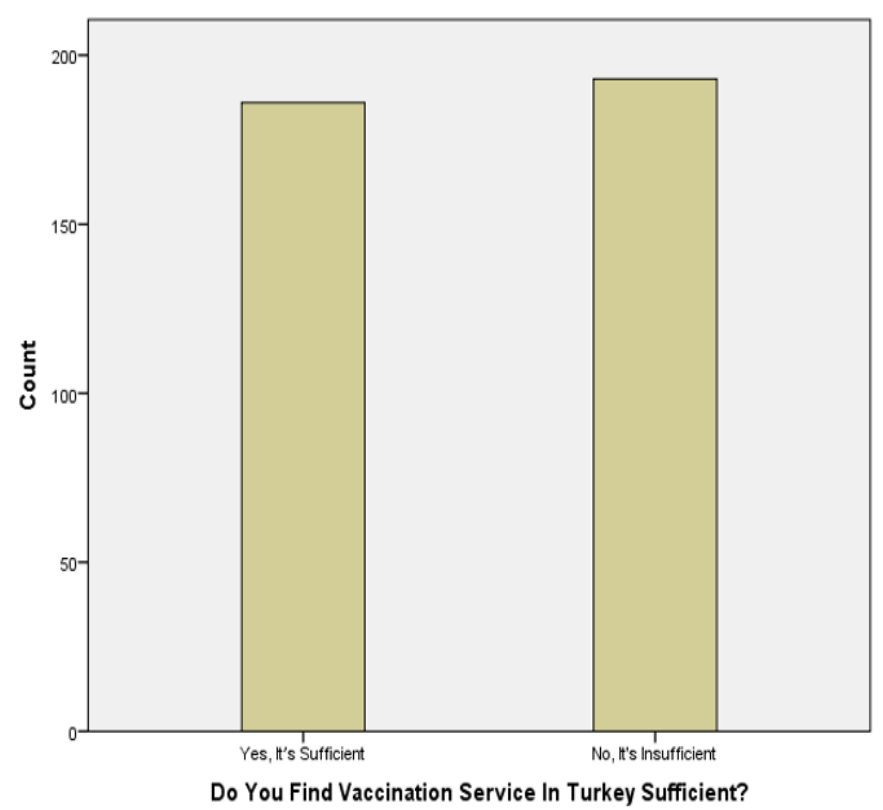

Figure 5: Participants thoughts on vaccination service in Turkey.

\section{DISCUSSION}

There might be differences in vaccination programs for each country. The two most important reasons for that are epidemiology and the presence of an effective, secure, and accessible vaccine (7). Designing vaccination programs and their implementation is carried out by the Ministry of Health, General Directo-

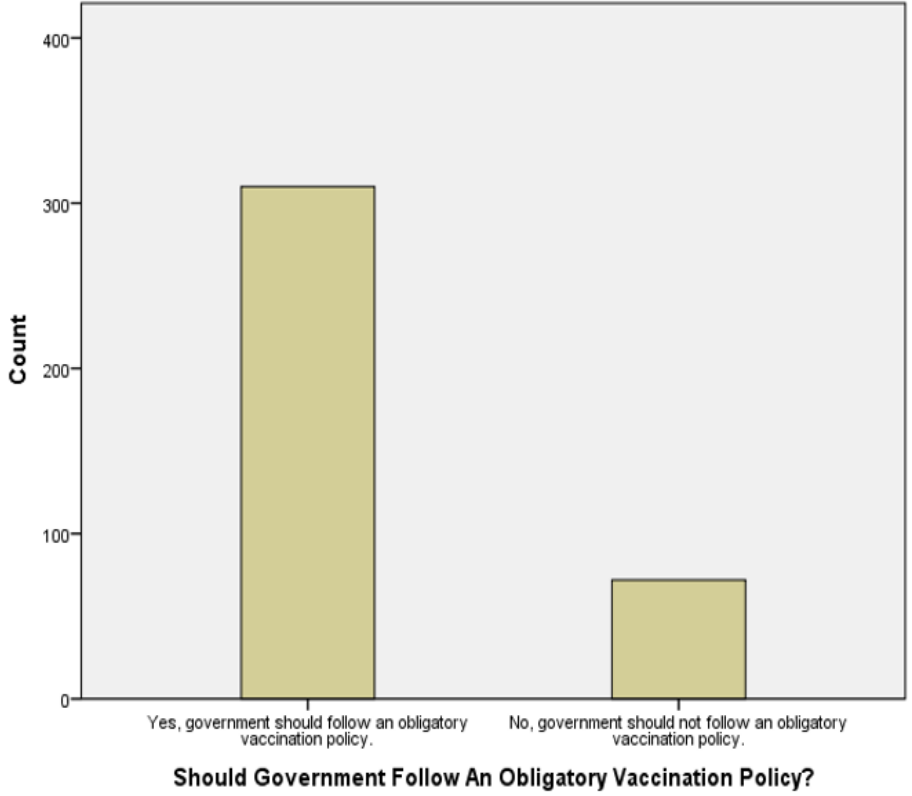

Figure 6: Participants thoughts on obligatory vaccination.

rate of Primary Health Care in the Turkish Republic. Expanded Immunization Program started in 1981 in Turkey (7). The up-to-date national childhood vaccination schedule of Turkey is shown in Table 5 (8).

The results of this study show that students in higher grades' knowledge levels are higher. Feher et al. (9) reported $6.5 \%$ of medical students in Hungary had flu vaccination coverage before education, and $24 \%$

Table 5: National childhood vaccination schedule of Turkish Republic.

\begin{tabular}{|c|c|c|c|c|c|c|c|c|c|c|c|}
\hline Age & Birth & $\begin{array}{c}1 \\
\text { month }\end{array}$ & $\begin{array}{c}2 \\
\text { months }\end{array}$ & $\begin{array}{c}3 \\
\text { months }\end{array}$ & $\begin{array}{c}4 \\
\text { months }\end{array}$ & $\begin{array}{c}6 \\
\text { months }\end{array}$ & $\begin{array}{c}12 \\
\text { months }\end{array}$ & $\begin{array}{c}18 \\
\text { months }\end{array}$ & $\begin{array}{c}24 \\
\text { months }\end{array}$ & $\begin{array}{c}\text { Primary } \\
\text { school } \\
\left(1^{\text {st }}\right. \\
\text { grade })\end{array}$ & $\begin{array}{c}\text { Secondary } \\
\text { school } \\
\left(8^{\text {th }} \text { grade }\right)\end{array}$ \\
\hline Hepatitis B & I & II & & & & III & & & & & \\
\hline$B C G$ & & & I & & & & & & & & \\
\hline DTaP-IPV-Hib & & & I & II & III & & & $\mathrm{R}$ & & & \\
\hline$P C V$ & & & I & II & & & $\mathrm{R}$ & & & & \\
\hline$M M R$ & & & & & & & I & & & II & \\
\hline DTap-IPV & & & & & & & & & & $\mathrm{R}$ & \\
\hline$O P V$ & & & & & & I & & II & & & \\
\hline$T d$ & & & & & & & & & & & $\mathrm{R}$ \\
\hline Hepatitis A & & & & & & & & I & II & & \\
\hline Chickenpox & & & & & & & I & & & & \\
\hline
\end{tabular}

BCG: Bacillus Calmette-Guérin DTaP-IPV-Hib: Diphtheria, Tetanus, Pertussis, Polio, Haemophilus influenzae Type b PCV: Pneumococcal conjugate vaccine MMR: measles, mumps, rubella DTap-IPV: Diphtheria, Tetanus, Pertussis, Polio OPV: oral polio vaccine Td: Tetanus, Diphtheria 
of students uninformed about the schedule cannot be ignored. To reduce this number medicine, pharmacy and nursing faculties should focus on the benefits of vaccination in the education curriculum.

Every year, almost 3 million children around the world die of diseases preventable with vaccines (10). The main reason is that efficient immunization for children has a low rate (10). There are three hypotheses of the anti-vaccination movement. The first claim is that Measles, Mumps, Rubella (MMR) vaccine causes the intestinal membrane to break, therefore causing absorption of enzymes causing encephalopathy. The second claim is that ethyl mercury, which is an ingredient of vaccines, is toxic for the central nervous system, and the third claim is that vaccines suppress and weaken the immune system when applied at the same time (11).

In this study, almost all of the students said they would vaccinate their children in the future so it can be said that the anti-vaccination movement is not very common among students in healthcare.

There are still some arguments about studies claiming that vaccination is the cause of autism, ADHD, neurologic diseases, inflammatory bowel diseases, and some immune system dysfunctions. This causes the anti-vaccination movement to grow and some organizations to rise (12). However, there are some strong studies performed against the idea of vaccines causing autism are showing that thimerosal and mercury inside the vaccines or MMR vaccines do not cause autism (13-15). The majority of participants stated they do not believe that vaccines cause autism. Greenberg et al. (16) reported a concerning number of parents who believe or are uncertain about there is a link between vaccines and autism (28\%). However, since the population of our study consisted of students who are going to be healthcare providers, the results of our study are different than Greenberg et al. (16).

Many diseases that may cause mortality or morbidity are preventable with vaccination. Tetanus cases reported by the European Union in 2014 consisted of $65 \%$ adults. Each adult with unregistered tetanus vaccination information should complete their vaccination by having three doses of adult diphtheria-tetanus vaccine (Td). All adults who have completed their primary vaccine series should get a $\mathrm{Td}$ vaccine every 10 years. There are also other vaccines that need to be taken before traveling, pilgrimage, and Umrah visits or because of chronic diseases (17).

Influenza vaccine is recommended for people older than 6 months with risk factors but no contraindication and people older than 65 years with no contraindi- cation (18). Clinical trials showed influenza vaccines to have a $60 \%$ positive impact on people older than 65 (19).

Christini et al. (20) reported $63 \%$ of medical students were vaccinated for influenza. Walker et al. (21) reported $53.8 \%$ of Australian medical students received most recent influenza vaccine in 2014 and inconvenience was the most common barrier to vaccination among Australian students. In our study, the ratio of getting regularly vaccinated is very low with $16.3 \%$ compared to literature. Our results may be caused by personal preferences or lack of education.

Active vaccines are manufactured from a weakened microorganism that causes the disease. Vaccines manufactured this way contain microorganisms and create immune response but do not cause the disease. This type of vaccines should not be used in immunosuppressive patients. Bacillus Calmette-Guêrin (BCG), oral polio, MMR, and chickenpox vaccines are examples of active vaccines. Inactive vaccines such as Hepatitis $A$, hepatitis $B$, inactive polio, and pneumococcal vaccines may contain whole microorganisms or only its antigenic units (22).

In this study, $50.9 \%$ of students stated that they do not find vaccination services enough, and $81.2 \%$ of the students stated that government should follow an obligatory vaccination policy. Accordingly, it can be thought that the students came to this conclusion: If vaccination would not be obligatory, it would not be correctly followed by individuals themselves or anti-vaxxer parents would not vaccinate their children. According to these results and health students' high ratio of awareness about vaccination, in the future, these students might improve vaccination services, search for ideas, create awareness, change behavior, or determine the reason why vaccination services are not enough.

Vaccination in Turkey in recent years has become a controversial issue especially in terms of vaccines applied to children. The issue went ahead of the judiciary, and the Supreme Court ruled that the children could be vaccinated without the consent of their legal representatives. However, upon the decisions of the Constitutional Court that forbid vaccination without consent, the decisions of the Supreme Court changed in this direction. In order to make the administration use vaccination authority, this authority must be based on the law. If the authority is granted by law and also the consent is not stipulated as a condition, the administration does not need the consent of the person concerned about vaccination (23).

This study has some limitations that should be noted. Firstly, our questionnaire was completed by 383 
students, further studies with more participants may give different results. Secondly, volunteers of this study consisted of only Trakya University students. Thirdly, only the first three grades of medical students were included in this study although all of the grades of other faculties were included. Fourthly, there are merely 4 questions asked for testing the knowledge level of participants however other questions asked for finding out habits and thoughts of the participants.

In conclusion, healthcare students who have knowledge about vaccines and vaccination can orient both the people around them and their patients correctly in their future professional lives. They can help solve this timely problem by transferring the correct information to the public against vaccine-preventable diseases and anti-vaxxers. In order to make students more informed about vaccines and vaccination, it may be beneficial to include this subject more in the curriculum and to carry out more informative studies on the subject.

Ethics committee approval: This study was approved by the Scientific Research Ethics Committee of Trakya University School of Medicine (Protocol Code: TÜTF-BAEK 2019-475).

Informed consent: Written informed consent was obtained from the participants of this study.

Financial disclosures: The authors declared that this study received no financial support.

Conflict of Interest: The authors declared no conflict of interest.

Author contributions: Concept: EK, ASY, BNM, FKO Design: EK, ASY, BNM, FKO Supervision: EK, ASY, BNM, FKO Resources: EK, ASY, BNM, FKO Materials: EK, ASY, BNM, FKO Data collection and/or processing: EK, ASY, BNM, FKO Analysis and/or Interpretation: EK, ASY, BNM, FKO Literature Search: EK, ASY, BNM, FKO Writing Manuscript: EK, ASY, BNM, FKO Critical Review: EK, ASY, BNM, FKO.

\section{REFERENCES}

1. Barker JP. Mercury, vaccines, and autism. Am J Public Health 2008;98(2):244-53.

2. Wessel L. Vaccine myths. Science 2017;356(6336):368-72.

3. Campbell-Scherer D. Evidence from large Danish cohort does not support an association between the MMR vaccine and autism: facts in a post-truth world. BMJ Evid Based Med 2019;24(5):198-9. 4. Taylor B, Miller E, Farrington CP et al. Autism and measles, mumps, and rubella vaccine: no epidemiological evidence for a causal association. Lancet 1999;353(9169):2026-9.

5. Y. Tony Yang, Jana Shaw. Sudden infant death syndrome, attention-deficit/hyperactivity disorder and vaccines: Longitudinal population analyses. Vaccine 2018 Jan 29;36(5):595-8.

6. Centers for Disease control and Prevention. Vaccines: The basics.
2012 March (cited 2020 April 2). Available from: URL:https://www. cdc.gov/vaccines/vpd/vpd-vac-basics.html.

7. Özmert EN. Dünya'da ve Türkiye'de aşılama takvimindeki gelişmeler. Çocuk Sağlığı ve Hastalıkları Dergisi 2008;51:168-75.

8. National Childhood Vaccination Schedule of Turkish Republic. Available from: URL: https://asi.saglik.gov.tr/asi-takvimi/

9. Feher A, Fekete M, Varga JT. Medical students' knowledge level on vaccinology. Orvosi Hetilap 2019;160(30):1193-9.

10. Ahmet Arvas. Aşılamada yapılan hatalar. Türk Pediatri Arşivi 2004;39:9-13.

11. Gerber JS, Offit PA. Vaccines and autism: a tale of shifting hypotheses. Clin Infect Dis 2009;48(4):456-61.

12. Gülcü S, Arslan S. Çocuklarda aşı uygulamaları: güncel bir gözden geçirme. Düzce Üniversitesi Sağlık Bilimleri Enstitüsü Dergisi 2018;8(1):34-43.

13. Taylor LE, Swerdfeger AL, Eslick GD. Vaccines are not associated with autism: an evidence-based meta-analysis of case-control and cohort studies. Vaccine 2014;32(29):3623-9.

14. Jain A, Marshall J, Buikema A et al. Autism occurrence by MMR vaccine status among US children with older siblings with and without autism. JAMA 2015;313(15):1534-40.

15. Hviid A, Hansen JV, Frisch $M$ et al. Measles, mumps, rubella vaccination and autism: a nationwide cohort study. Ann Intern Med 2019;170(8):513-20.

16. Greenberg J, Dube E, Driedger M. Vaccine hesitancy: in search of the risk communication comfort zone. PLoS Curr 2017;9.

17. Turkish Republic Ministry of Health Vaccine Portal. Adulthood vaccination. Available from: URL: https://asi.saglik.gov.tr/asi-kimlere-yapilir/liste/30-yetişkin-aşllama.html.

18. Centers for Disease Control and Prevention (CDC). Who should and who should not get a flu vaccine. Available from: URL: https://www.cdc.gov/flu/prevent/whoshouldvax.html.

19. Ribaudo AS, Hayney MS. Influenza vaccine formulation and effectiveness. Journal of The American Pharmacists Association 2017;57(5):637-9.

20. Christini $A B$, Shutt KA, Byers KE. Influenza vaccination rates and motivators among healthcare worker groups. 2007;28(2):171-7. 21. Walker L, Newall A, Heywood AE. Knowledge, attitudes and practices of Australian medical students towards influenza vaccination. Vaccine 2016;34(50):6193-9.

22. Turkish Republic Ministry of Health Vaccine Portal. Vaccine types. Available from: URL: https://asi.saglik.gov.tr/genel-bilgiler/41-asi-turleri.html.

23. Akkoyunlu SA. Genel sağlığın korunmasına ilişkin idari bir faaliyet olarak aşı uygulamasının kanunuliği. Erzincan Üniversitesi Hukuk Fakültesi Dergisi 2017;21(1-2):43-73. 